Berkala Ilmu Perpustakaan dan Informasi, Vol. 13, No. 2, Desember 2017, Hal. 155-165 DOI: http://10.22146/bip.27494

ISSN 1693-7740 (Print), ISSN 2477-0361 (Online)

Tersedia online di https://jurnal.ugm.ac.id/bip

\title{
PEMANFAATAN KOLEKSI PERPUSTAKAAN FAKULTAS HUKUM UNIVERSITAS GADJAH MADA UNTUK KARYA AKHIR MAHASISWA: KAJIAN ANALISIS SITASI
}

\author{
Ikhwan Arif ${ }^{1}$ \\ ${ }^{1}$ Pustakawan Universitas Gadjah Mada \\ e-mail: ikhwan@ugm.ac.id
}

Naskah diterima: 15 Agustus 2017, direvisi: 29 September 2017, disetujui: 16 Oktober 2017

\begin{abstract}
ABSTRAK
Salah satu cara untuk menilai keberhasilan pengembangan koleksi di Perpustakaan Fakultas Hukum Universitas Gadjah Mada (UGM) dengan melakukan evaluasi koleksi dengan teknik analisis sitasi. Tujuan penelitian ini adalah untuk mengetahui penggunaan koleksi Perpustakaan Fakultas Hukum UGM sebagai sumber referensi dalam karya akhir mahasiswa. Adapun metode penelitian yang digunakan dalam penelitian ini yakni diskriptif kuantitatif. Sampel penelitian 80 judul karya akhir mahasiswa meliputi skripsi, tesis dan disertasi Fakultas Hukum UGM tahun 2016. Hasil penelitian menunjukkan bahwa mayoritas referensi yang digunakan dalam tugas akhir mahasiswa menggunakan literatur buku dan tingkat ketersediaan literatur di Perpustakaan Fakultas Hukum UGM yakni sebesar 64\%.
\end{abstract}

Kata kunci: Analisis Sitasi; bibliometrik; evaluasi literatur perpustakaan

\section{ABSTRACT}

One way to assess the success of collection development in the Library of Faculty of Law Universitas Gadjah Mada (UGM) is by conducting collection evaluation by using a citation analysis technique. The study aims to determine the use of UGM Faculty of Law Library collection as a reference source in the students' final papers. The research used descriptive quantitative approach. The samples were 80 students' final papers in the Faculty of Law in 2016. The results show that the majority of references used were books and the level of collection availability in the Library was $64 \%$.

Keywords: Citation analysis; bibliometrics; evaluation of library collection.

\section{A. PENDAHULUAN}

Keberadaan perpustakaan di lingkungan pendidikan tinggi menjadi penting fungsinya untuk menunjang visi misi dan Tri Darma Perguruan Tinggi. Keberadaan perpustakaan sudah menjadi icon akan kebesaran suatu perguruan tinggi. Semakin bagus perpustakaan yang dimilikinya maka aura yang melekat di perguruan tinggi tersebut juga tampak megah. Tidak ada perguruan tinggi yang besar tanpa adanya perpustakaan.

Diakui bahwa perpustakaan dengan gedung yang baik dengan koleksi yang lengkap secara psikologis akan menumbuhkan kegairahan mahasiswa untuk datang dan menggunakan fasilitas perpustakaan tersebut. Namun demikian tingginya minat pemustaka yang berkunjung ke perpustakaan bukan menjadi tolok ukur utama bagi keberhasilan sebuah perpustakaan perguruan tinggi di era teknologi informasi sekarang ini.

Banyak faktor untuk menilai keberhasilan suatu perpustakaan diantaranya dengan melihat tingkat pemanfaatan koleksi yang dikelolanya. Cara pertama untuk melihat tingkat pemanfaatan koleksi di perpustakaan perguruan 
tinggi dengan melihat tingkat keterpakaian koleksi yang dilakukan secara langsung dengan dibaca di tempat atau dipinjam serta diakses melalui media secara online dengan internet. Cara kedua dengan melihat seberapa jauh pemustaka menggunakan koleksi perpustakaan sebagai referensi dalam penulisan ilmiah seperti untuk tugas akhir skripsi, tesis dan disertasi. American Library Association (ALA, 1990) menyebutkan bahwa kriteria yang paling fundamental bagi perpustakaan perguruan tinggi koleksi yang memenuhi kebutuhan informasi primer pemustakanya. Saunders (1983) menyatakan bahwa perpustakaan harus memahami kebutuhan informasi sivitas akademika, yakni bahan literatur apa yang secara faktual dibaca (in fact read) dan apa yang seharusnya dibaca (ought to read). Salah satu cara untuk memahami kebutuhan informasi pemustaka tersebut dengan melakukan evaluasi koleksi. Perpustakaan Fakultas Hukum UGM melakukan analisis sitasi karya akhir mahasiswa sebagai usaha mengetahui tingkat pemanfaatan koleksi yang ada dan mengetahui literatur yang dibutuhkan oleh pemustaka.

Guna mewujudkan perpustakaan yang baik Perpustakaan Fakultas Hukum UGM sebagai pusat layanan dan sumber informasi hukum yang lengkap, bermutu berbasis teknologi guna mendukung kegiatan penelitian dan pendidikan pascasarjana sesuai dengan visi dan misi Perpustakaan UGM. Beberapa usaha perbaikan menuju perpustakaan yang berkualitas telah dilakukan antara lain dengan berpindah ruang gedung. Sebelumnya perpustakaan menempati salah satu ruangan di Gedung 4 yang luasnya $400 \mathrm{~m}^{2}$ kini menempati gedung tersendiri yang luasnya mencapai $1200 \mathrm{~m} 2$ sehingga dapat menampung lebih banyak koleksi dan pemustaka. Selain perluasan sarana gedung juga perpanjangan waktu layanan perpustakaan selama 4 jam setiap harinya yaitu pukul 16.00 s.d $20.00 \mathrm{wib}$.

Untuk memperbanyak literatur ilmu hukum Perpustakaan Fakultas Hukum UGM setiap tahun mengembangkan koleksinya dalam bentuk cetak maupun digital. Pengembangan koleksi cetak prioritas utama dengan melakukan pengadaan buku baru baik lokal Indonesia dan buku asing khususnya Inggris. Untuk koleksi digital Perpustakaan Fakultas Hukum mendapat support dari Perpustakaan Pusat UGM dengan dilanggankan database khusus bidang hukum Westlaw maupun database lain seperti Jstor, Ebsco yang jumlahnya lebih dari 50 database.

Berdasarkan paparan di atas maka perumusan masalah dalam penelitian ini yakni jenis literatur apa yang digunakan oleh pemustaka untuk menyusun karya akhir dan seberapa besar tingkat ketersediaan literatur tersebut di Perpustakaan Fakultas Hukum UGM.

Adapun tujuan dari penelitian adalah 1) untuk mengetahui jenis literatur yang disitir dalam karya akhir, 2) bahasa literatur yang disitir dalam karya akhir, dan 3) tingkat ketersediaan literatur yang disitir dalam karya akhir.

\section{B. TINJAUAN PUSTAKA}

a. Keaslian Penelitian

Berdasarkan hasil penelusuran, penulis menemukan beberapa penelitian serupa yang pernah dilakukan beberapa peneliti sebelumnya. Adapun penelitian serupa yang telah dilakukan oleh Gasparotto (2014) dan Rohyanti Zulaikha (2002) melakukan penelitian tentang analisis bibliografi pada disertasi, ditemukan bahwa koleksi buku paling banyak disitir daripada jurnal. Penelitian sejenis juga dilakukan oleh Maryatun (2016) yang menunjukan tingkat pemanfaatan jurnal dalam database EBSCO sebagai sitiran penyusunan tesis dan disertasi mahasiswa program magister sains dan doktor FEB UGM masih sangat kurang, yaitu di bawah 20\%.

Melihat hasil penelitian yang telah dilakukan di atas maka dalam penelitian ini menunjukkan beberapa perbedaan yang khusus diantaranya meliputi:

1) Tingkat pemanfaatan jenis literatur yang digunakan oleh obyek penelitian yang lebih spesifik yaitu mahasiswa Fakultas Hukum UGM meliputi mahasiswa S1, S2 dan S3. 
2) Tingkat pemanfaatan jurnal yang dilanggan oleh UGM khususnya Westlaw yang digunakan dalam penulisan akhir mahasiswa.

Hasil penelitian di atas sangat bermanfaat untuk evaluasi pengembangan koleksi di Perpustakaan UGM umumnya dan Perpustakaan Fakultas Hukum UGM khususnya.

\section{b. Arti Penting Penelitian Evaluasi Koleksi}

Evaluasi koleksi atau literatur di perpustakaan penting dilakukan untuk menilai tingkat ketersediaan dan keterpakaiannya oleh pemustaka karena kuantitas dan kualitas literatur ikut mempengaruhi eksistensi perpustakaan karena perpustakaan yang baik adalah perpustakaan yang mampu menyediakan informasi yang dibutuhkan oleh pemustaka dan dapat membantu kegiatan ilmiah yang yang mereka lakukan. Hasil evaluasi koleksi dapat dijadikan dasar dalam pengembangan koleksi perpustakaan. Oleh karena itu perlu dilakukan bentuk kajian atau analisis melalui suatu kerangka penelitian ilmiah untuk mengetahui jenis, tingkat penggunaan dan ketersediaannya dalam memenuhi kebutuhan pemustaka.

\section{c. Evaluasi Pemanfaatan Koleksi}

Berdasarkan "The ALA's Guide to the Evaluation of Library Collection" metode evaluasi koleksi dapat dikategorikan menjadi dua, yaitu evaluasi yang berorientasi pada koleksi (collection-centered) dan evaluasi yang berorientasi pada pemanfaatan koleksi (usecentered). Metode evaluasi yang berorientasi pada pemanfaatan koleksi salah satunya ialah metode analisis sitiran (citation analysis). Adapun teknik untuk melakukan evaluasi koleksi yang biasa digunakan ada 2 cara yaitu dengan melihat pemanfaatan koleksi dan ketersediaan koleksi. Analisis sitiran dapat dijadikan alat evaluasi artikel yang disitir dalam karya ilmiah yang dihasilkan oleh komunitas pemustaka yang dilayani perpustakaan.

Evaluasi koleksi merupakan salah satu dari kegiatan pembinaan koleksi yang bertujuan untuk mengetahui secara lebih jelas siapa yang dilayani perpustakaan, koleksi apa saja yang dapat dimanfaatkan untuk perencanaan pengembangan bahan literatur lebih lanjut, bagaimana menilai koleksi agar relevansinya dapat dipertahankan (Pandit, 2007). Pengembangan koleksi perpustakaan harus selalu diarahkan kepada pemakai dan bukan hanya untuk memperoleh koleksi standar yang relatif. Evaluasi koleksi sebagai dasar pengembangan koleksi juga mencegah perpustakaan dikendalikan oleh individu atau keadaan yang memaksakan pembelian bahan literatur secara acak atau tidak sesuai dengan visi dan misi perpustakaan.

Adapun tujuan dari evaluasi koleksi pada perpustakaan perguruan tinggi adalah :

1. mengetahui mutu, lingkup, dan kedalaman koleksi

2. menyesuaikan koleksi dengan tujuan dan program perguruan tinggi

3. mengikuti perubahan, perkembangan sosial budaya, ilmu dan teknologi

4. meningkatkan nilai informasi

5. mengetahui kekuatan dan kelemahan koleksi

6. menyesuaikan kebijakan penyiangan koleksi (Dirjen DIKTI, 2005)

Sementara itu, pada tingkat yang lebih luas evaluasi koleksi bertujuan untuk mengetahui seberapa jauh koleksi yang ada dapat memenuhi kebutuhan informasi pengguna. Kebutuhan informasi pada lingkungan perguruan tinggi harus meliputi informasi tingkat dasar, informasi yang mendukung perkuliahan untuk tingkat sarjana dan informasi subjek khusus untuk kebutuhan penelitian (American Library Association, 1990).

\section{d. Analisis Sitasi atau Sitiran}

Pemanfaatan literatur perpustakaan baik itu buku maupun jurnal baik cetak maupun elektronik merupakan aktivitas pemustaka dalam menggunakan informasi dalam literatur tersebut untuk memenuhi kebutuhan informasi yang dibutuhkannya. Selain digunakan sebagai bahan bacaan, literatur juga digunakan sebagai dasar atas ide, gagasan atau temuan yang ditulis oleh seseorang dalam karya tulis yang mereka 
kerjakan. Daftar sitiran selanjutnya dikumpulkan dalam satu halaman akhir karya ilmiah yang diberi judul Daftar Pustaka.

Koleksi perpustakaan dievaluasi menggunakan analisis sitasi atau sitiran yang terdapat dalam daftar pustaka suatu karya ilmiah. Menurut Rupadha (2011) Analisis sitasi merupakan bagian dari bibliometrika yang melakukan analisis bersifat kuantitatif dengan menerapkan metode statistika dan perhitungan matematika sederhana terhadap bentuk komunikasi tertulis dan komunikasi terekam lainnya.

Menurut Broadus (2007), teknik dasar dari analisis sitasi dengan cara menghitung karya yang disitir oleh para penulis yang digunakan untuk mempersiapkan karya tulisnya atau paling tidak yang memberi andil atas terciptanya karya tulis tersebut. Analisis sitiran dapat dilakukan dengan mengamati data bibliografis literatur dari satu atau sejumlah terbitan tertentu. Selanjutnya data tersebut dicatat dan dianalisis untuk mengetahui karakteristik dari literatur yang digunakan berdasarkan subyek, bahasa, bentuk, serta usia dokumen yang disitir.

Menurut Sulistyo-Basuki (2006) analisis sitiran digunakan untuk mengukur pengaruh intelektual ilmuwan dari seorang pengarang yang disitir, karena beberapa studi sitiran literatur digunakan untuk mengetahui karakteristik komunikasi ilmu pengetahuan dan banyak aspek kualitatif dari penelitian dan publikasi.

Pendapat yang tidak jauh berbeda dikemukakan oleh Reitz (2006) yang menyatakan bahwa analisis sitasi acuan tertulis dari sebuah karya atau bagian sebuah karya yang dihasilkan oleh pengarang, penyunting, komposer dan sebagainya, yang dengan jelas mengidentifikasi suatu dokumen, di mana acuan karya itu diperoleh.

Adapun latar belakang seorang penulis melakukan sitiran menurut Andriani (2002) untuk memperkuat sebuah temuan, memberitahu pembaca tentang penelitian yang sudah dilakukan, menerangkan konsep atau teori, menunjukan karya lain yang berbeda dan sebagainya. Hal ini menunjukan bahwa karya ilmiah yang baru akan selalu mengacu atau merujuk pada karya terdahulu yang terkait. Satu tema penelitian untuk sebuah karya akademik yang akan disusun oleh seorang penulis akan selalu ada komunikasi ilmiah dengan tema penelitian yang sama atau hampir sama yang telah ada sebelumnya.

\section{METODE PENELITIAN}

Penelitian ini menggunakan metode deskriptif kuantitatif untuk mendapat data atau fakta tentang ragam dan tingkatan pemanfaatan literatur dalam penulisan tugas akhir mahasiswa Fakultas Hukum UGM.

\section{a. Populasi dan Sampel}

Populasi dalam penelitian ini berupa karya tulis akhir mahasiswa program studi S1 (skripsi), S2 (tesis) dan S3 (disertasi) Fakultas Hukum UGM tahun 2016. Adapun jumlah sampel yang dijadikan obyek penelitian sebanyak 80 seperti tercantum pada tabel 1 .

\begin{tabular}{|c|c|c|}
\hline Jenis & $\begin{array}{l}\text { Jumlah } \\
\text { Populasi }\end{array}$ & $\begin{array}{l}\text { Jumlah } \\
\text { Sampel }\end{array}$ \\
\hline Skripsi & 364 & 30 \\
\hline Tesis & 330 & 30 \\
\hline Disertasi & 23 & 20 \\
\hline Jumlah & 717 & 80 \\
\hline
\end{tabular}

Pengambilan sampel menggunakan teknik proportional sampling di mana sampel diambil dari berbagai departemen (Adat, Perdata, Pidana, dll) dan tingkatan strata program studi (S1, S2 dan S3) Fakultas Hukum (FH) UGM. Dengan teknik ini diharapkan akan didapatkan keberagaman sampel dari berbagai bidang kajian dan tingkatan strata pendidikan sehingga mewakili populasi yang ada.

\section{b. Teknik Pengumpulan Data}

Teknik yang digunakan dalam pengumpulan data dengan metode dokumentasi. Peneliti mengumpulkan semua file bibliografi atau daftar pustaka skripsi, tesis dan disertasi yang terpilih dijadikan sampel penelitian yang diunduh dari situs http://etd.repository.ugm.ac.id/. 
Setelah semua file dokumen $P D F$ terkumpul kemudian dilakukan seleksi, klasifikasi dan migrasi data ke Microsoft Excel 2013.

\section{c. Bahan dan Instrumen Penelitian}

Dalam penelitian ini, bahan dan instrumen penelitian yang digunakan meliputi:

1. Data file bilbliografi skripsi, tesis dan disertasi sebanyak 80 judul.

2. Situs katalog perpustakaan http://etd.repository.ugm.ac.id/.

3. Software Microsoft Excel 2013

4. Akses atau jaringan internet

\section{d. Analisis Data}

Metode analisis menggunakan tabel frekuensi dalam persentase. Penghitungan persentase menggunakan rumus sederhana seperti berikut: Persentase $(\%)=($ bagian $/$ seluruh bagian)x100. Hasil perhitungan persentase diinterpretasikan menggunakan kategori standar analisis data dari Arikunto (1998) seperti berikut: Nilai 81 - 100\% : sangat baik; Nilai 61 - 80\% : baik; Nilai $41-60 \%$ : cukup; Nilai 21 $40 \%$ : kurang; Nilai 0 - 20\%: sangat kurang.

Adapun langkah-langkah dalam melakukan analisis sitiran dalam penelitian ini adalah sebagai berikut:

1. Mengumpulkan data bibliografi tugas akhir mahasiswa FH UGM tahun 2016

2. Melakukan seleksi daftar bibliografi yang akan dijadikan sampel penelitian

3. Melakukan konversi data dari file PDF mejadi file yang bisa diolah dalam Microsoft Excel

4. Melakukan klasifkasi data dalam berbagai kategori berdasar jenis karya akhir, jenis literatur, bahasa, tahun terbit dan lain sebagainya.

5. Mencocokkan daftar sitasi/sitiran sampel dengan koleksi Perpustakaan Fakultas Hukum UGM.

6. Membuat analisis data melalui berbagai kategori data seperti: jenis, tahun, bahasa dan lain sebagainya sesuai dengan kebutuhan informasi yang diinginkan.

\section{HASIL DAN PEMBAHASAN \\ a. Koleksi Perpustakaan Fakultas Hukum UGM}

Berdasarkan hasil observasi data di Perpustakaan Fakultas Hukum UGM didapatkan statistik koleksi seperti ditunjukkan dalam tabel 2.

\begin{tabular}{|c|c|c|c|c|c|c|c|}
\hline \multirow{3}{*}{ No. } & \multirow{3}{*}{$\begin{array}{c}\text { Jenis } \\
\text { Koleksi }\end{array}$} & \multicolumn{6}{|c|}{ Tahun } \\
\hline & & \multicolumn{2}{|c|}{2014} & \multicolumn{2}{|c|}{2015} & \multicolumn{2}{|c|}{2016} \\
\hline & & Judul & Eks. & Judul & $\mathrm{Eks}$ & Judul & $\mathrm{Eks}$ \\
\hline 1 & Teks & 7511 & 22423 & 7979 & 24809 & 8234 & 25306 \\
\hline 2 & Referensi & 1336 & 2022 & 1346 & 2171 & 1367 & 2195 \\
\hline 3 & Jurnal & 114 & 1.029 & 114 & 1029 & 116 & 1131 \\
\hline 4 & Penelitian & 264 & 382 & 271 & 271 & 271 & 271 \\
\hline 5 & Skripsi & 5614 & 5614 & 5946 & 5946 & 6298 & 6298 \\
\hline 6 & Tesis & 3754 & 3754 & 4348 & 4348 & 4781 & 4781 \\
\hline \multirow[t]{2}{*}{7} & Disertasi & 60 & 60 & 81 & 81 & 111 & 111 \\
\hline & Jum lah & & & 20085 & 38655 & 21178 & 40093 \\
\hline
\end{tabular}

Perkembangan koleksi paling banyak berupa literatur jenis buku. Sejak 2014 jumlah buku terjadi peningkatan sebanyak 723 judul 2883 eksemplar. Menurut pustakawan Perpustakaan Fakultas Hukum UGM, kenaikan jumlah judul dan eksemplar buku tersebut merujuk pada usulan kebutuhan buku dari pemustaka dan penawaran buku yang masuk ke perpustakaan tersebut.
Koleksi jenis referensi secara fisik tidak mengalami peningkatan jumlah yang berarti. Hal ini disebabkan kebijakan untuk mengurangi koleksi jenis buku-buku referensi seperti ensiklopedi, kamus, peraturan dan perundangundangan yang banyak tersedia dalam bentuk digital. Koleksi digital utama adalah database yang dilanggan secara periodik oleh UGM seperti: Westlaw, JSTOR, EBSCO, Scopus dan 
lain sebagainya. Selain database berbayar tersebut perpustakaan juga mengenalkan berbagai database gratis baik itu bentuk undang-undang (peraturan) dan jurnal online yang ada di berbagai situs internet seperti terhimpun di Directory of Open Access Journals.

\section{b. Jenis Literatur}

Berdasarkan hasil pengolahan data sitiran karya tulis akhir mahasiswa dari berbagai tingkatan strata program studi didapatkan data seperti tabel 3 .

Tabel 3 Jenis Literatur yang Disitir

\begin{tabular}{|c|c|c|c|c|c|c|c|c|c|}
\hline \multirow{2}{*}{ No } & \multirow{2}{*}{ Jenis Literatur } & \multicolumn{2}{|c|}{ Skripsi } & \multicolumn{2}{|c|}{ Tesis } & \multicolumn{2}{|c|}{ Disertasi } & \multirow{2}{*}{ Jumlah } & \multirow{2}{*}{$\%$} \\
\hline & & $\mathrm{Jm} 1$ & Rerata & $\mathrm{Jm} 1$ & Rerata & $\mathrm{Jm} 1$ & Rerata & & \\
\hline 1 & Buku & 838 & 28 & 926 & 31 & 2444 & 122 & 4.208 & 64 \\
\hline 2 & UU \& Peraturan & 387 & 13 & 255 & 8.5 & 290 & 14.5 & 932 & 14 \\
\hline 3 & Artikel Internet & 212 & 7 & 211 & 7 & 246 & 12.3 & 669 & 10 \\
\hline 4 & Artikel Jurnal & 102 & 3.4 & 46 & 1.5 & 309 & 15.4 & 457 & 7 \\
\hline 5 & Makalah & 79 & 26 & 36 & 1.2 & 111 & 5.5 & 226 & 3 \\
\hline 6 & Skripsi & 42 & 1.4 & 7 & 0.2 & 0 & 0 & 49 & 0.7 \\
\hline 7 & Tesis & 9 & 0.3 & 36 & 1.2 & 2 & 0.1 & 47 & 0.7 \\
\hline 8 & Disertasi & 1 & 0.03 & 0 & 0 & 36 & 1.8 & 37 & 0.5 \\
\hline & Jum lah & 1.675 & 56 & 1.517 & 51 & 3.450 & 173 & 6.625 & 100 \\
\hline
\end{tabular}

Tabel 3 menunjukkan bahwa mahasiswa menggunakan sitiran dalam tugas akhir mereka sebanyak 6625/80 (total sitiran/jumlah sampel) sebesar 83 sitiran. Karya akhir program studi S3 (disertasi) paling banyak menggunakan sitiran, yaitu sebanyak 173, program studi S1 (skripisi) 56 sitiran dan paling sedikit menggunakan sitiran program studi S2 (tesis) sebanyak 51 sitiran.

Berdasarkan jumlah tersebut, literatur jenis buku menjadi pilihan pertama dengan jumlah sitiran 64\%, kedua literatur jenis perundangundangan dan peraturan sebanyak $14 \%$, ketiga sitiran yang bersumber dari internet $10 \%$. Urutan ke empat sitiran dari jurnal dengan jumlah sitiran sebanyak 6,4\% . Kelima sitiran dari makalah dengan jumlah sitiran sebesar $4,1 \%$. Urutan ke 6, 7 dan 8 skripsi, tesis dan disertasi, jumlah sitiran dari jenis ini kurang dari $1 \%$. Ilustrasi dalam bentuk grafik jenis literatur yang digunakan sebagai sumber referensi dalam penulisan skripsi, tesis dan disertasi dapat dilihat dalam gambar.

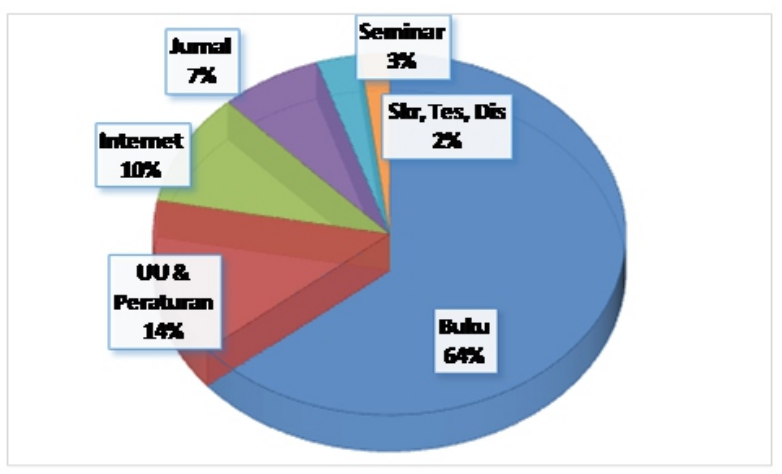

Gambar 1. Persentase Jenis Informasi Yang Disitir

c. Jumlah Sitiran Berdasarkan Jenis Karya

Jenis karya akhir mahasiswa dengan jumlah sitiran tertinggi jenis karya disertasi dengan jumlah sitiran setiap judulnya sebesar 173, kedua jenis karya skripsi dengan jumlah 56 sitiran dan ketiga jenis karya tesis dengan jumlah 51. Berdasarkan hasil tersebut ternyata rata-rata jumlah sitiran skripsi lebih banyak dari pada jumlah sitiran tesis yang terpaut 5 sitiran. Namun demikian keduanya terpaut jauh dari jumlah sitiran disertasi yang terpaut 100 lebih sitiran. Ilustrasi jumlah rata-rata sitiran setiap judul berdasarkan kategori jenis karya akhir mahasiswa dapat dilihat dalam gambar berikut ini. 


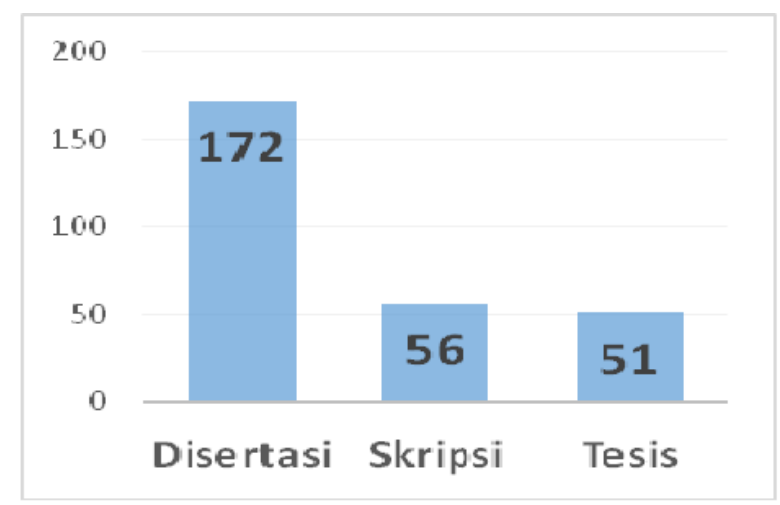

Gambar 2 Rata-rata Jumlah Sitiran Berdasar Jenis Karya Akhir

\section{d. Bahasa Literatur}

Berdasarkan bahasa literatur yang digunakan sebagai sumber referensi penulisan karya akhir mahasiswa Fakultas Hukum UGM tahun 2016 maka penggunaan literatur bahasa Indonesia menempati peringkat pertama sebesar 95\%, kedua 4.84\% menggunakan literatur bahasa Inggris, sisanya kurang dari $0.2 \%$ menggunakan literatur bahasa Arab, Belanda dan Perancis.

\begin{tabular}{clrr}
\multicolumn{4}{c}{ Tabel 4. Bahasa Literatur yang Disitir } \\
\hline Urutan & Bahasa & Jumlah & Persentase \\
\hline 1 & Indonesia & 6293 & $95 \%$ \\
2 & Inggris & 321 & $4,84 \%$ \\
3 & Belanda & 7 & $0,10 \%$ \\
4 & Arab & 2 & $0,03 \%$ \\
5 & Perancis & 2 & $0.03 \%$ \\
\hline & & 6625 & $100 \%$ \\
\hline
\end{tabular}

Sedikitnya mahasiswa yang menggunakan bahasa asing terutama Inggris sebagai sumber referensi perlu dikaji ulang untuk mengetahui alasannya.

\section{e. Ketersediaan Literatur}

Berikut ini hasil pengolahan data dengan cara mencocokan data sitiran tugas akhir mahasiswa dengan literatur yang tersedia di perpustakaan.

Tabel 5 Tingkat Ketersediaan Literatur

\begin{tabular}{clccccc}
\hline No & Jenis Karya & Judul & Sitiran & Ada & Persentase & Kategori \\
\hline 1 & Skripsi & 30 & 1.458 & 1.022 & $70 \%$ & Baik \\
2 & Tesis & 30 & 1.306 & 1.036 & $79 \%$ & Baik \\
3 & Disertasi & 20 & 3.192 & 1.714 & $54 \%$ & Cukup \\
& Jumlah & 80 & 5.956 & 3.772 & $63 \%$ & Baik \\
\hline
\end{tabular}

Tingkat ketersediaan literatur Perpustakaan Fakultas Hukum UGM yang digunakan untuk karya akhir mahasiswa Fakultas HukumUGM tahun 2016 sebesar 63\%. Adapun rincian tingkat ketersediaan literatur untuk karya akhir mahasiswa tiga tingkatan program studi adalah sebagai berikut:

1. Ketersediaan literatur untuk karya -akhir skripsi sebesar 70\% (kategori baik).

2. Ketersediaan literatur untuk karya akhir tesis sebesar 79\% (kategori baik)

3. Ketersediaan literatur untuk karya tulis disertasi sebesar 54\% (kategori cukup).

Ilustrasi tingkat ketersediaan literatur untuk karya akhir mahasiswa ditunjukan dalam gambar berikut.

Gambar 3 Persentase Ketersediaan Literatur

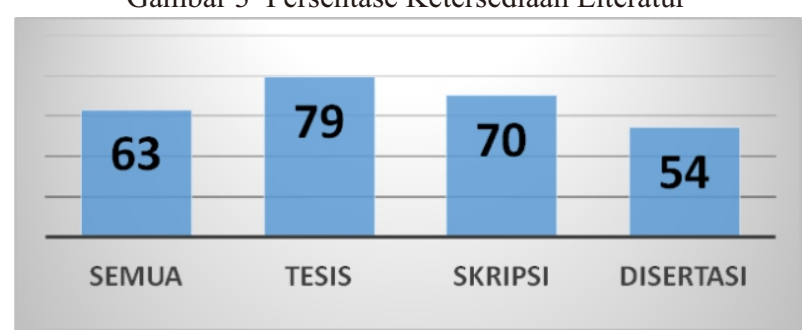

Secara umum ketersediaan literatur dapat dikatakan baik, namun demikian perlu ditingkatkan baik judul maupun jenis koleksinya agar tingkat ketersedianya dapat meningkat, terutama untuk memenuhi kebutuhan penulisan karya akhir disertasi yang tingkat ketersediaanya baru mencapai 54\%. Hasil ini dapat menjadi evaluasi sebagai bahan kajian judul dan jenis literatur yang perlu ditambah untuk memenuhi kebutuhan tersebut.

Dalam penelitian ini sitiran yang bersumber dari internet penulis sengaja tidak menghitung karena beberapa alasan berikut:

1. Materi informasi internet secara fisik tidak ada di perpustakaan namun bisa mudah didapatkan melalui fasilitas internet di perpustakaan sehingga menyulitkan dalam menghitung tingkat ketersediaanya literatur secara menyeluruh. 
2. Materi dan teknik penulisan informasi dari internet banyak yang tidak memiliki standar seperti informasi dalam buku maupun jurnal dan sejenisnya.

3. Banyak informasi di internet banyak yang tidak memiliki properti kelengkapan literatur seperti penulis, tahun, tempat terbit dan sebagainya.

\section{f. Ketersediaan Buku}

Statistik pengolahan data ketersediaan sitiran yang bersumber dari literatur buku untuk penulisan tugas akhir mahasiswa FH UGM 2016.

Tabel 6 Ketersediaan Buku

\begin{tabular}{|c|c|c|c|c|c|c|}
\hline $\begin{array}{l}\text { Kategori } \\
\text { Karya }\end{array}$ & $\begin{array}{l}\text { Jumlah } \\
\text { Sampel }\end{array}$ & $\begin{array}{l}\text { Jumlah } \\
\text { Sitiran }\end{array}$ & $\begin{array}{l}\text { Sitiran } \\
\text { Tersedia }\end{array}$ & $\begin{array}{l}\text { Rerata } \\
\text { Sitiran }\end{array}$ & $\begin{array}{l}\text { Persentase } \\
\text { Tersedia }\end{array}$ & Kategori \\
\hline Skripsi & 30 & 838 & 687 & 28 & $82 \%$ & Sangat baik \\
\hline Tesis & 30 & 926 & 790 & 31 & $85 \%$ & Sangat baik \\
\hline \multirow[t]{2}{*}{ Disertasi } & 20 & 2.444 & 1.344 & 122 & $55 \%$ & Cukup \\
\hline & 80 & 4.208 & 2.821 & 35 & $67 \%$ & Baik \\
\hline
\end{tabular}

Pada tabel di atas menunjukkan bahwa tingkat ketersediaan buku untuk memenuhi penulisan karya akhir mahasiswa di 3 program studi mencapai 67\% (baik). Perlu dicermati bahwa jumlah sitiran bersumber literatur dari jenis buku di masing-masing jenis karya akhir berbeda-beda. Untuk disertasi rata-rata menggunakan 122, tesis 31, skripsi 28 sitiran. Catatan penting dari tabel 6 untuk Perpustakaan Fakultas Hukum UGM tingkat ketersediaan buku yang dijadikan sumber sitiran penulisan karya akhir disertasi yang tingkat ketersediaannya baru mencapai 55\% sehingga perlu ditingkatkan ketersediaannya.

\section{g. Penggunaan Buku Berdasarkan Bahasa}

Hasil pengolahan data penggunaan sitiran yang bersumber dari buku bahasa Inggris.

Tabel 7 Penggunaan Sitiran dari Buku Berbahasa Inggris

\begin{tabular}{lcccccc}
\hline Kategori & Jumlah & Indonesia & Inggris & $\begin{array}{c}\text { Ada } \\
\text { Inggris }\end{array}$ & $\begin{array}{c}\text { Rerata } \\
\text { Inggris }\end{array}$ & $\begin{array}{c}\text { Tersedia } \\
\text { Inggris }\end{array}$ \\
\hline Skripsi & 30 & 724 & 114 & 36 & 4 & $32 \%$ \\
Tesis & 30 & 876 & 50 & 23 & 1.6 & $46 \%$ \\
Disertasi & 20 & 2.185 & 259 & 72 & 13 & $28 \%$ \\
\hline & 80 & 3.634 & 423 & 66 & 4 & $21 \%$ \\
\hline
\end{tabular}

Penggunaan literatur bersumber dari buku bahasa Inggris sebesar $11.6 \%$, dengan perhitungan 423 sitiran berbahasa Inggris dibagi 3634 sitiran berbahasa Indonesia dikalikan 100.
Penggunaan sitiran yang bersumber dari buku berbahasa Inggris dari tiga jenis karya akhir strata program studi (skripsi, tesis dan disertasi) masih tergolong rendah karena masing-masing judul rata-rata menggunakan 4 sitiran. Rendahnya penggunaan sitiran yang bersumber dari buku berbahasa Inggris dalam penulisan karya akhir mahasiswa terutama tesis yang jumlah sitirannya kurang dari 2 untuk setiap karya akhir penelitian perlu dikaji untuk mengetahui penyebabnya. Sedangkan masih rendahnya tingkat ketersediaan buku berbahasa Inggris yang dijadikan sumber sitiran juga dijadikan bahan evaluasi dalam melakukan seleksi pengadaan buku bahasa Inggris. Dilanggannya database online dapat menjadi alternatif bagi mahasiswa atas kurangnya ketersediaan buku dalam bahasa Inggris.

\section{h. Ketersediaan Jurnal}

Berikut hasil pengolahan data sitiran yang bersumber dari literatur jenis jurnal ditunjukan dalam tabel berikut:

\begin{tabular}{lccccc}
\multicolumn{5}{c}{ Tabel 8 Rekap Sitiran Jurnal } \\
\hline Kategori & Sampel & Sitiran & Ada & Rerata & Ketersediaan \\
\hline Skripsi & 30 & 102 & 50 & 3.4 & $49 \%$ \\
Tesis & 30 & 46 & 21 & 1.5 & $45 \%$ \\
Disertasi & 20 & 309 & 80 & 15 & $25 \%$ \\
\hline & 80 & 457 & 150 & 6 & $33 \%$ \\
\hline
\end{tabular}

Secara keseluruhan jumlah sitiran yang bersumber dari artikel jurnal sebanyak 7\% dari total jumlah sitiran. Jika diambil rata-rata maka setiap karya akhir mahasiswa menggunakan sitiran bersumber jurnal sebanyak 6 sitiran. Kelompok program studi paling sedikit menggunakan sitiran dari literatur jurnal adalah karya akhir mahasiswa S2 (tesis) di mana ratarata hanya 1.5 sitiran per judul tesis. Rendahnya mahasiswa program studi S2 menggunakan sitiran dari literatur jurnal perlu dikaji mendalam untuk mengetahui penyebabnya.

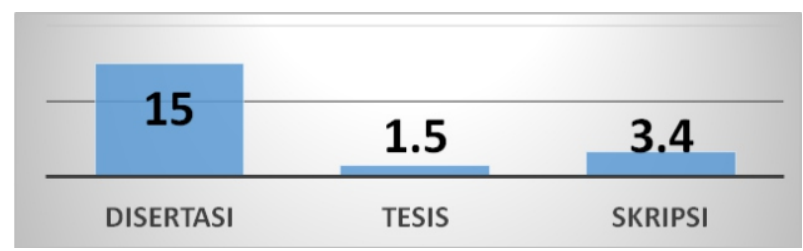

Gambar 5 Penggunaan Jurnal Menurut Jenis Karya 


\section{i. Jenis Jurnal}

Berikut hasil pengolahan data sitiran jurnal berdasarkan jenis bahasa.

Tabel 9 Kategori Jenis Jurnal yang Disitir

\begin{tabular}{lcc}
\hline Jenis Jurnal & Sitiran & Persentase \\
\hline Jurnal Indonesia & 311 & $68 \%$ \\
Jurnal berbahasa Inggris & 146 & $32 \%$ \\
\hline \multicolumn{1}{c}{ Jumlah } & 457 & 100 \\
\hline
\end{tabular}

Berikut hasil menunjukan bahwa jurnal Indonesia lebih banyak digunakan (68\%) sedangkan jurnal Inggris digunakan sebesar $32 \%$.

\section{j. Penggunaan Jurnal Berbahasa Inggris}

Berikut hasil pengolahan data sitiran yang bersumber pada literatur jenis jurnal berbahasa Inggris.

Tabel 11 Sitiran Jurnal Berbahasa Inggris

\begin{tabular}{lrrrrr}
\hline Kategori & Sampel & Sitiran & Tersedia & Rerata & Ketersediaan \\
\hline Skripsi & 30 & 44 & 24 & 0.8 & $54 \%$ \\
Tesis & 30 & 26 & 11 & 0.4 & $42 \%$ \\
Disertasi & 20 & 171 & 48 & 2.3 & $28 \%$ \\
\hline & 80 & 241 & 83 & 3 & $34 \%$ \\
\hline
\end{tabular}

Secara keseluruhan penggunaan sitiran bersumber dari jurnal berbahasa Inggris masih sedikit yaitu rata-rata 3 sitiran di setiap judul karya akhir. Perlu kajian untuk mengetahui penyebab rendahnya mahasiswa menggunakan literatur jenis jurnal berbahasa Inggris. Adapun rincian penggunaan jurnal berbahasa Inggris dalam 3 jenis penelitian mahasiswa sebagai berikut:

- Tingkat penggunaan jurnal berbahasa Inggris pada jenis skripsi dan tesis sangat rendah karena di bawah $1 \%$ dengan tingkat ketersediaan jurnal sebesar $42 \%$ dan $54 \%$.

- Jumlah penggunaan jenis disertasi rata-rata sebanyak 1 judul, tingkat ketersediaan jurnal di perpustakaan sebesar $28 \%$.

Berikut jurnal-jurnal yang dijadikan sumber referensi.
Tabel 12 Daftar Jurnal yang Disitir

\begin{tabular}{|c|c|c|}
\hline $\begin{array}{l}\text { Jumlah } \\
\text { Sitiran }\end{array}$ & $\begin{array}{c}\text { Asal } \\
\text { Jurnal }\end{array}$ & Nama Jurnal \\
\hline 14 & Lokal & $\begin{array}{l}\text { Mimbar Hukum } \\
\text { The American Journal of International }\end{array}$ \\
\hline 7 & Westlaw & Law \\
\hline 5 & Lokal & Jurnal Tata Negara \\
\hline 4 & Lokal & Jurnal Ilmu Hukum \\
\hline 4 & Lokal & Jurnal Keadilan \\
\hline 3 & Scopus & Arab Law Quarterly \\
\hline 3 & Lokal & Jurnal Dinamika Hukum \\
\hline 3 & Lokal & $\begin{array}{l}\text { Jurnal Konstitusi } \\
\text { Singapore Year Book of International }\end{array}$ \\
\hline 3 & Westlaw & Law \\
\hline 2 & Proquest & Contemporary Southeast Asia \\
\hline 2 & westlaw & Harvard Law Review \\
\hline 2 & Jstor & International Journal \\
\hline 2 & Lokal & Jurnal Hukum \\
\hline 2 & Lokal & Jurnal Hukum Bisnis \\
\hline 2 & Lokal & Jurnal Hukum Jentera \\
\hline 2 & Lokal & Jurnal Hukum Progresif \\
\hline 2 & Lokal & $\begin{array}{l}\text { Jurnal Ilmiah Hukum Legality } \\
\text { Law Review, Universitas Pelita }\end{array}$ \\
\hline 2 & Lokal & Harapan \\
\hline 2 & Lokal & $\begin{array}{l}\text { Varia Peradilan } \\
\text { African Journal of Business and }\end{array}$ \\
\hline 1 & Ebsco & $\begin{array}{l}\text { Economic Research } \\
\text { American University International Law }\end{array}$ \\
\hline 1 & Westlaw & $\begin{array}{l}\text { Review } \\
\text { Annals of the Association of American }\end{array}$ \\
\hline 1 & Scopus & Geographers \\
\hline 1 & Proquest & Antitrust Bulletin/proquest \\
\hline 1 & Westlaw & Berkeley Journal of International Law \\
\hline 1 & Westlaw & $\begin{array}{l}\text { Brooklyn Journal of International Law } \\
\text { Case West ern Journal of International }\end{array}$ \\
\hline 1 & westlaw & Law \\
\hline 1 & westlaw & Columbia Journal of Law and the Arts \\
\hline 1 & westlaw & Cornell International Law Journal \\
\hline 1 & proquest & $\begin{array}{l}\text { Economics Week (Atlanta, GA) } \\
\text { European Journal of International }\end{array}$ \\
\hline 1 & westlaw & Relations \\
\hline 1 & Lokal & Fiat Yustisia \\
\hline 1 & westlaw & Fordham International Law Journal \\
\hline 1 & westlaw & Industrial Law Journal \\
\hline 1 & proquest & International Organization \\
\hline 1 & scopus & Journal of Economic Literature \\
\hline 1 & ebsco & Journal of Economic Perspectives \\
\hline 1 & westlaw & Journal of International Economic Law \\
\hline 1 & proquest & Journal of World Investment \& Trade \\
\hline 1 & Lokal & Jurnal Hukum Ius Quia Iustium \\
\hline 1 & Lokal & Jurnal Pembaharuan Hukum \\
\hline 1 & Lokal & Jurnal Sosio humaniora \\
\hline 1 & jstor & Law and Contemporary Problems \\
\hline 1 & westlaw & Leiden Journal of International Law \\
\hline 1 & Lokal & Lex Administratum \\
\hline 1 & westlaw & Marquette Law Review \\
\hline 1 & westlaw & $\begin{array}{l}\text { Modern law review } \\
\text { Review of International Political }\end{array}$ \\
\hline 1 & scopus & Economy \\
\hline 1 & scopus & The Pacific Review \\
\hline 1 & scopus & $\begin{array}{l}\text { The Pakistan Development Review } \\
\text { The Quarterly Review of Economics }\end{array}$ \\
\hline 1 & ebsco & and Finance \\
\hline 1 & westlaw & The Yale Law Journal/scopus \\
\hline 1 & westlaw & Virginia Journal of International Law \\
\hline 1 & Lokal & Warta \\
\hline 1 & scopus & World Trade Review \\
\hline 1 & Lokal & Yustisia \\
\hline 1 & scopus & Oxford Journal of Legal Studies \\
\hline 1 & jstor & Law and Contemporary Problems \\
\hline 1 & ebsco & Potchefstroom Electronic Law Journal \\
\hline
\end{tabular}




\section{k. Penggunaan Makalah}

Berikut hasil pengolahan data sitiran jenis makalah.

\begin{tabular}{lrrrrr}
\multicolumn{7}{c}{ Tabel 13 Statistik Sitiran Makalah } \\
\hline Kategori & Sam pel & Sitiran & Tersedia & Rerata & Ketersediaan \\
\hline Skripsi & 30 & 44 & 24 & 0.8 & $54 \%$ \\
Tesis & 30 & 26 & 11 & 0.4 & $42 \%$ \\
Disertasi & 20 & 171 & 48 & 2.3 & $28 \%$ \\
\hline & 80 & 241 & 83 & 3 & $34 \%$ \\
\hline
\end{tabular}

Jumlah literatur yang bersumber dari makalah sebanyak 4\% sedangkan rata-rata penggunaan makalah sebagai sumber referensi sangat rendah yaitu 3 sitiran untuk setiap judulnya sedangkan tingkat ketersediaan makalah di Perpustakaan Fakultas Hukum UGM juga sangat kecil yakni 11\%. Rendahnya tingkat

ketersediaan makalah di Perpustakaan Fakultas Hukum UGM antara lain karena artikel makalah kebanyakan di publikasikan dalam jumlah terbatas dalam acara-acara tertentu seperti seminar, lokakarya, pengukuhan dan sejenisnya.

\section{Penggunaan Literatur Peraturan dan Perundang-undangan}

Berikut ini statistik hasil pengolahan data sitiran yang bersumber dari literatur jenis peraturan dan perundang-undangan.

Tabel 14 Statistik Sitiran Peraturan dan Perundang -

\begin{tabular}{lrrr}
\multicolumn{4}{c}{ undangan } \\
\hline Kategori & Jumlah & \multicolumn{1}{c}{ Sitiran } & \multicolumn{1}{c}{ Rerata } \\
\hline Skripsi & 30 & 387 & 8 \\
Tesis & 30 & 255 & 7 \\
Disertasi & 20 & 290 & 13 \\
\hline & 80 & 932 & 12
\end{tabular}

Rata-rata jumlah sitiran dari literatur peraturan dan perundang-undangan yakni 12 .

\section{m. Penggunaan Karya Akhir Mahasiswa Skripsi, Tesis dan Disertasi}

Berikut ini hasil pengolahan data dari karya akhir mahasiswa.

Tabel 15 Penggunaan Laporan Penelitian Skripsi, Tesis dan Disertasi

\begin{tabular}{ccrrrrrr}
\hline No & Jenis & Jumlah & Skripsi & Tesis & Disertasi & Jum 1ah & Rerata \\
\hline 1 & Skripsi & 30 & 42 & 7 & 0 & 49 & 1.6 \\
2 & Tesis & 30 & 9 & 36 & 2 & 47 & 1.56 \\
3 & Disertasi & 20 & 1 & 0 & 36 & 37 & 1.8 \\
\hline Jum lah & 80 & 52 & 43 & 38 & 133 & 1.66 \\
\hline
\end{tabular}

Penggunaan sitiran bersumber literatur karya akhir skripsi, tesis dan disertasi dalam karya akhir mahasiswa relatif kecil atau sedikit karena rata-rata penggunaannya kurang dari 2 judul atau kurang dari $2 \%$ total sitiran.

Berdasarkan hasil analisis dan pembahasan didapatkan hasil penelitian sebagai berikut:

- Sumber literatur yang digunakan dalam penulisan karya akhir mahasiswa Fakultas Hukum UGM tahun 2016 sebagai berikut: buku 64\%, peraturan (perundangperudangan) $14 \%$, internet $10 \%$, jurnal $7 \%$, makalah $3 \%$, dan karya penelitian mahasiswa (skripsi, tesis dan disertasi) $2 \%$.

- Bahasa yang digunakan $95 \%$ bahasa Indonesia, 4,8\% menggunakan bahasa Inggris, dan sisanya $0.2 \%$ menggunakan bahasa Arab, Belanda dan Perancis

- Tingkat ketersediaan literatur yang digunakan sebagai sumber referensi penulisan karya akhir mahasiswa (skripsi, tesis dan disertasi) Fakultas Hukum UGM tahun 2016 di Perpustakaan Fakultas Hukum UGM adalah sebesar 63\% atau dalam kategori cukup.

\section{E. KESIMPULAN}

Berdasarkan penelitian ini didapatkan kesimpulan sebagai berikut:

1. Jenis literatur yang paling banyak digunakan buku

2. Bahasa literatur yang dominan digunakan bahasa Indonesia

3. Tingkat pemanfaatan database (jurnal) yang dilanggan oleh UGM sangat rendah

\section{DAFTAR PUSTAKA}

Arikunto, S. (1998). Manajemen penelitian, Rineka Cipta, Jakarta

Andriani, J., 2002. Studi Kualitatif Mengenai Alasan Menyitir Dokumen: Kasus pada Lima Mahasiswa Program Pascasarjana IPB. Jurnal Perpustakaan Pertanian Vol. 11 No. 2

Broadus, R. N. (2007). An investigation of the validity of bibliographic citations. Journal of the American Society for Information Science. 
Departemen Pendidikan dan Kebudayaan RI. (2005). Buku Pedoman Perpustakaan Perguruan Tinggi. Jakarta : Dirjen Dikti

Maryatun; Irianti, P., (2016). Pemanfaatan Database EBSCO dan ProQuest sebagai Rujukan Penyusunan Tesis dan Disertasi bagi Mahasiswa Program Magister Sains dan Doktor Fakultas Ekonomika dan Bisnis UGM: Analisis Sitiran Jurnal Ilmiah. Berkala Ilmu Perpustakaan dan Informasi, Vol. 12 No 2 (123-135).

Gasparotto, M. (2014). A ten year analysis of dissertation bibliographies from the Department of Spanish and Portuguese at Rutgers University", Collection Building, Vol. 33 (3) pages 86-89.

Pandit, P.L.. (2007). Perpustakaan Digital: perspektif perpustakaan perguruan tinggi Indonesia. Jakarta: Sagung Seto
Rupadha, I K. (2011). Memahami Karakteristik Kebutuhan Informasi Peneliti dengan Metode Analisis Sitasi. Makalah Seminar dan Temu Ilmiah Pustakawan, Universitas Mataram.

Sulistyo-Basuki. (2006). Bibliometrika, Sainsmetrika dan Infometrika. Kumpulan Makalah Kursus Bibliometrika. Depok: Masyarakat Informetrika Indonesia. 20-23 Mei 2002.

Saunders, S. (1983). "Student Reliance on Faculty Guidance in the Selection of Reading Materials: The Use of Core Collections", Collection management Vol. 4(4).

Zulaikha, S.R. (2002). Kajian analisis sitasi terhadap skripsi mahasisa IAIN Sunan Kalijaga di UPT Perpustakaan IAIN Sunan Kalijaga Yogyakarta: Suatu evaluasi keterpakaian koleksi perpustakaan ditinjau dari analisis sitasi. Tesis. Yogyakarta: Universitas Gadjah Mada. 